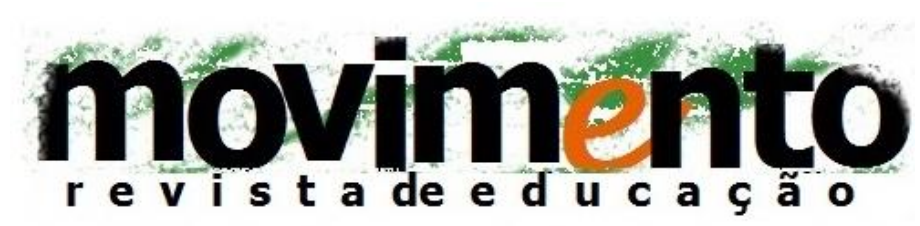

faculdade de educação - programa de pós-graduação em educação

universidade federal fluminense

issn 2359-3296

ano 3 número 5 - 2016

\title{
REFORMA DO ENSINO MÉDIO DO (DES) GOVERNO DE TURNO: decreta-se uma escola para os ricos e outra para os pobres 1
}

\author{
Gaudêncio Frigotto2
}

A reforma de ensino médio proposta pelo bloco de poder que tomou o Estado brasileiro por um processo golpista, jurídico, parlamentar e midiático, liquida a dura conquista do ensino médio como educação básica universal para a grande maioria de jovens e adultos, cerca de $85 \%$ dos que frequentam a escola pública. Uma agressão frontal à constituição de 1988 e a Lei de Diretrizes da Educação Nacional que garantem a universalidade do ensino médio como etapa final de educação básica.

Os proponentes da reforma, especialistas analfabetos sociais e doutores em prepotência, autoritarismo e segregação social, são por sua estreiteza de pensamento e por condição de classe, incapazes de entender o que significa educação básica. E o que é pior, se entende não a querem para todos.

Com efeito, por rezarem e serem co-autores da cartilha dos intelectuais do Banco Mundial, Organização Mundial do Comércio, etc., seus compromissos não são com direito universal à educação básica, pois a consideram um serviço que tem que se ajustar às demandas do mercado. Este, uma espécie de um deus que

1 Publicado originariamente no portal da ANPEd em 22/09/2016. www.anped.org.br

2 Filósofo e Educador. Professor do Programa de Pós Graduação em Políticas Públicas e Formação Humana da Universidade do Estado do Rio de Janeiro (UERJ). 


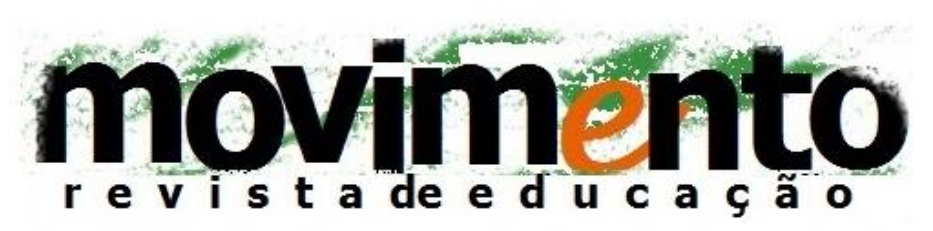

faculdade de educação - programa de pós-graduação em educação

universidade federal fluminense

issn 2359-3296

ano 3 número 5 - 2016

define quem merece ser por ele considerado num tempo histórico de desemprego estrutural. O ajuste ou a austeridade que se aplica à classe trabalhadora brasileira, da cidade e do campo, pelas reformas da previdência, reforma trabalhista e congelamento por vinte anos na ampliação do investimento na educação e saúde públicas, tem que chegar à escola pública, espaço onde seus filhos estudam.

A reforma do ensino médio que se quer impor por Medida Provisória segue figurino da década de 1990 quando MEC era dirigido por Paulo Renato de Souza no Governo Fernando Henrique Cardoso. Não por acaso Maria Helena Guimarães é a que de fato toca o barco do MEC. Também não por acaso que o espaço da mídia empresarial golpista é dado a figuras desta década.

Uma reforma que retrocede ao obscurantismo de autores como Desttut de Tracy que defendia, ao final do século XIX, ser da própria natureza e, portanto, independente da vontade dos homens, a existência de uma escola rica em conhecimento, cultura, etc., para os que tinham tempo de estudar e se destinavam a dirigir no futuro e outra escola rápida, pragmática, para os que não tinham muito tempo para ficar na escola e se destinavam (por natureza) ao duro ofício do trabalho.

Neste sentido é uma reforma que anula Lei №. 1.821 de 12 de março de 1953. Que dispõe sobre o regime de equivalência dos cursos de grau médio para efeito de matrícula nos curso superiores e cria novamente, com outra nomenclatura, o direcionamento compulsório à universidade. Um direcionamento que camufla o fato de que para a maioria da classe trabalhadora seu destino são as carreiras de menor prestigio social e de valor econômico. 


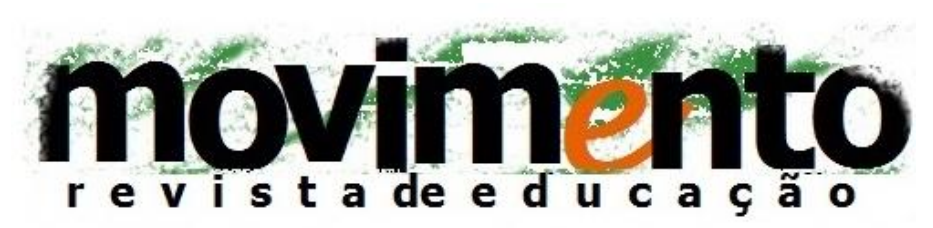

faculdade de educação - programa de pós-graduação em educação

universidade federal fluminense

issn 2359-3296

ano 3 número 5 - 2016

Também retrocede e torna, e de forma pior, a reforma do ensino médio da ditadura civil militar que postulava a profissionalização compulsória do ensino profissional neste nível de ensino. Piora porque aquela reforma visava a todos e esta só visa os filhos da classe trabalhadora que estudam na escola pública. Uma reforma que legaliza o apartheid social na educação no Brasil.

O argumento de que há excesso de disciplinas esconde o que querem tirar do currículo - filosofia, sociologia e diminuir a carga de história, geografia, etc. E o medíocre e fetichista argumento que hoje o aluno é digital e não agüenta uma escola conteudista mascara o que realmente o aluno desta, uma escola degradada em seus espaços, sem laboratórios, sem auditórios de arte e cultura, sem espaços de esporte e lazer e com professores esfacelados em seus tempos trabalhando em duas ou três escolas em três turnos para comporem um salário que não thes permite ter satisfeitas as suas necessidades básicas. Um professorado que de forma crescente adoece. Os alunos do Movimento Ocupa Escolas não pediram mais aparelhos digitais, estes eles têm nos seus cotidianos. Pediram justamente condições dignas para estudar e sentir-se bem no espaço escolar.

Por fim, uma traição aos alunos filhos dos trabalhadores, ao achar que deixando que eles escolham parte do currículo vai ajuda-los na vida. Um abominável descompromisso geracional e um cinismo covarde, pois seus filhos e netos estudam nas escolas onde, na acepção de Desttut de Tracy estudam os que estão destinados a dirigir a sociedade. Um reforma que legaliza a existência de uma escola diferença para cada classe social. Justo estes intelectuais que em seus escritos negam a existência das classes sociais. 


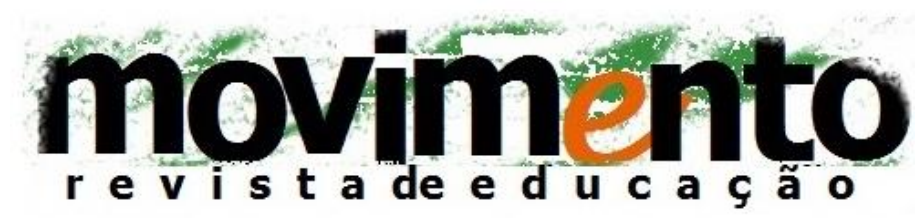

faculdade de educação - programa de pós-graduação em educação

universidade federal fluminense issn 2359-3296

ano 3 número 5 - 2016

Quando se junta prepotência do autoritarismo, arrogância, obscurantismo e desprezo aos direitos da educação básica plena e igual para todos os jovens, o seu futuro terá como horizonte a insegurança e a vida em suspenso. 